\title{
PENGARUH KEPUASAN KERJA TERHADAP KINERJA PEGAWAI KANTOR KELURAHAN SEKABUPATEN BATANG HARI
}

\author{
Kasiyati Yunita Wulansari, Niki Kosasi \\ STIE Graha Karya Muara Bulian, Jambi, Indonesia
}

\begin{abstract}
This study raised concerns about the effect of job satisfaction to performance. The research was conducted within the scope of the precisely on the entire village in Batang Hari Regency. The performance of employees is among the key issues are constantly faced by the organization management. Therefore, among the tasks of the manager is a very important move employees to contribute to the success of the organization. The purpose of this study is to examine and determine the influence of job satisfaction and performance. Influence of job satisfaction and employee performance tested directly. To examine issues directly above the survey conducted by distributing questionnaires to employees village office. The results of the questionnaire were analyzed qualitatively and verification. Data analysis tool made by using Path Analysis. The results of this study indicate that the job satisfaction have an impact on performance $21,72 \%$.
\end{abstract}

Keyword: job satisfaction, employee performance

\section{PENDAHULUAN}

Mengingat pentingnya peranan sumber daya manusia ini dalam suatu organisasi tentunya sumber daya manusia tersebut perlu untuk dikelola sedemikian rupa, dan hal ini merupakan bagian penting dari pekerjaan menejemen organisasi yang bersangkutan. Menurut Robins (2002), proses manejemen sumber daya manusia pada akhirnya harus diukur dari segi seberapa efektif para menejer mengelola sumber daya manusia yang dimiliki. Dalam konteks ini, pengelolaan sumber daya manusia yang efektif tercermin dari produktivitas atau kinerja yang disumbangkan oleh pegawai. Dengan demikian dapatlah dikatakan bahwa kinerja dari para pegawai merupakan diantara isuisu pokok yang senantiasa dihadapi oleh menejemen organisasi. Karena itu, diantara tugas-tugas para menejer yang sangat penting adalah menggerakkan para pegawai guna memberi kontribusi bagi keberhasilan organisasi.

Peranan sumber daya manusia dalam organisasi, baik organisasi yang menganut sistem pelayanan non profit maupun profit sangat penting. Sebab tanpa sumber daya manusia maka apapun bentuk peralatan tehnologi dan secanggih apapun peralatan tehnologi yang dimiliki oleh organisasi tersebut tidak akan dapat difungsikan secara optimal. Disamping itu, jika asset ini terabaikan bukan tidak mungkin akan mengganggu aktivitas organisasi secara keseluruhan.

Mengingat pentingnya peranan sumber daya manusia ini dalam suatu organisasi tentunya sumber daya manusia tersebut perlu untuk dikelola sedemikian rupa, dan hal ini merupakan bagian penting dari pekerjaan menejemen organisasi yang bersangkutan. Menurut Robins (2002), proses manejemen sumber daya manusia pada akhirnya harus diukur dari segi seberapa efektif para menejer mengelola sumbe rdaya manusia yang dimiliki. Dalam konteks ini, pengelolaan sumber daya manusia yang efektif tercermin dari produktivitas atau kinerja yang disumbangkan oleh pegawai. Dengan demikian dapatlah dikatakan bahwa kinerja dari para pegawai merupakan diantara isuisu pokok yang senantiasa dihadapi oleh menejemen organisasi. Karena itu, diantara tugas-tugas para menejer yang sangat penting adalah menggerakkan para pegawai guna memberi kontribusi bagi keberhasilan organisasi.

Pada dasarnya, kepuasan kerja merupakan merupakan hal yang bersifat individu. Setiap individu memiliki tingkat 
kepuasan yang berbeda-beda sesuai dengan sistem nilai-nilai yang berlaku pada dirinya. Ini disebabkan karena adanya perbedaan pada masing-masing individu. Semakin banyak aspek-aspek yang sesuai dengan keinginan individu tersebut, maka semakin tinggi tingkat kepuasan yang dirasakannya. Sebaliknya, jika semakin sedikit aspekaspek dalam pekerjaannya yang tidak sesuai dengan keinginan individu tersebut, maka semakin rendah tingkat kepuasan yang dirasakan individu tersebut.

Menurut Tiffin yang dikutip oleh Edy Sutrisno (2009) yang menyatakan bahwa kepuasan kerja berhubungan erat dengan sikap dari karyawan terhadap pekerjaannya sendiri, situasi kerja, kerja sama antara pimpinan dengan para karyawan. Sedangkan Yulk dan Wexley menyatakan bahwa kepuasan kerja sebagai perasaan seseorang terhadap pekerjaannya.

\section{Kerangka Pemikiran}

Dengan memperhatikan kepuasan kerja pegawai, diharapkan mampu meningkatkan kinerja. kepuasan kerja terhadap kinerja tersebut secara skematik dapat distrukturkan dalam kerangka konseptual penelitian sebagai berikut :

\begin{tabular}{c|c|}
\hline $\begin{array}{c}\text { Kepuasan Kerja } \\
(\mathrm{X})\end{array}$ & $\rightarrow$ \\
$\begin{array}{c}\text { Kinerja } \\
(\mathrm{Y})\end{array}$ \\
\hline
\end{tabular}

Gambar 1. Kerangka Pemikiran

\section{METODE PENELITIAN Lokasi Penelitian}

Adapun objek penelitian dari penelitian ini adalah seluruh Kantor Kelurahan yang ada di dalam lingkup Kabupaten Batang Hari. Adapun kantor tersebut adalah Kantor Kelurahan Muara Bulian, Kantor Kelurahan Pasar Baru, Kantor Kelurahan Rengas Condong, Kantor Kelurahan Teratai, Kantor Kelurahan Sridadi, Kantor Kelurahan Muara Tembesi, Kantor Kelurahan Kembang Paseban, Kantor Kelurahan Sungai Rengas, Kantor Kelurahan Durian Luncuk, Kantor Kelurahan Jembatan Mas, Kantor
Kelurahan Terusan dan Kantor Kelurahan Bajubang.

\section{Populasi dan Sampel}

Populasi dalam penelitian ini adalah keseluruhan pegawai yang bekerja pada Kantor Kelurahan Sekabupaten Batang Hari yang tercatat yang berjumlah 167 orang. Kesemua populasi meliputi berbagai jenjang karir yang meliputi sekretaris lurah sampai dengan staf kelurahan.

Untuk menentukan besarnya sampel yang akan dijadikan responden, peneliti mengacu pada pendapat Arikunto (2010). Arikunto dalam melakukan perhitungan ukuran sampel yang diperoleh menyatakan bahwa apabila populasi di bawah 100 maka diambil semuanya untuk dijadikan sampel. Tapi jika populasi di atas 100 maka diambil $10-25 \%$. Dalam hal ini populasi berjumlah 167 orang, maka sampel yang diambil sebesar $30 \%$ dari populasi yang berarti jumlah sampel sebanyak 50 orang.

\section{Jenis dan Sumber Data}

Data primer adalah data yang diperoleh dengan cara penelitian dilapangan, yaitu data diperoleh dari para pegawai Kantor Kelurahan yang ada dalam lingkup Kabupaten Batang Hari dengan melakukan penyebaran kusioner. Data Sekunder adalah data yang diperoleh dengan cara mengadakan penelitian kepustakaan dan dokumen kepegawaian, dokumen kerja, dan dokumen lainnya yang berasal dari tiap Kantor Kelurahan.

Data-data yang didapat bersumber dari dalam (internal) Kantor Kelurahan seKabupaten Batang Hari, seperti : data para pegawai, dan data lain yang mendukung. Sedangkan data eksternal bersumber dari literatur-literatur yang berkaitan dengan masalah yang diteliti.

\section{Metode Pengumpulan Data}

Dalam memperoleh data, digunakan metode survey yaitu dengan menggunakan perangkat kuesioner terstruktur yang diajukan pada responden. Format kuesioner terdiri dari dua bagian utama, bagian 
pertama menyangkut pertanyaanpertanyaan umum mengenai karakteristik pegawai dan bagian kedua berisi pertanyaan masalah pokok penelitian. Itemitem pertanyaan diantaranya adalah seperti telah dikemukakan sebelumnya. Pengumpulan data dilakukan dengan pertama-tama meminta kesediaan para responden untuk berpartisipasi dalam penelitian ini, kemudian menyampaikan perangkat kuesioner penelitian untuk diisi oleh responden.

\section{Tehnik Analisis Data}

Dalam menganalisis dan menginterpretasikan data dan informasi dalam penelitian ini, penulis menggunakan pendekatan analisa statistik/ verifikatif.

1) Path Analysis

Untuk menjawab permasalahan menggunakan analisis jalur (Path Analysis) yang merupakan suatu metode pendekomposisian korelasi ke dalam bagian-bagian yang berbeda untuk menginterprestasikan suatu pengaruh/efek. Metode Path Analysis ini juga digunakan untuk menelaah hubungan antara model kausal yang dirumuskan atas dasar pertimbangan teoritis dan pengetahuan tertentu. Hubungan kausal selain didasarkan pada data, juga didasarkan pada pengetahuan, perumusan hipotesis dan analisis logis, sehingga dapat dikatakan Path Analysis ini dapat digunakan untuk menguji seperangkat hipotesis kausal serta untuk menafsirkan hubungan tersebut.

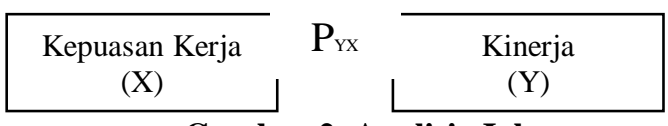

Gambar 2. Analisis Jalur

Untuk persamaan hubungan struktural diagram jalur diatas dinyatakan dengan persamaan sebagai berikut :

1. Pengaruh $X$ terhadap $Y$

- Pengaruh langsung

$\mathrm{X} \rightarrow \mathrm{Y}=$ PYX. PYX

2) $\mathrm{Uji} t$

Uji $\mathrm{t}$ digunakan untuk melihat pengaruh secara parsial antara variabel eksogen dan variabel endogen. Berdasarkan hasil pengujian uji t, maka akan diperoleh suatu hasil berupa $\mathbf{t}$ hitung yang akan dibandingkan dengan t tabel. Adapun rumus uji $\mathrm{t}$ adalah sebagai berikut :

$t_{\text {hitung }}=\frac{r \sqrt{n-2}}{\sqrt{1-r^{2}}}$

Keterangan :

$t=$ Nilai $t_{\text {hitung }}$

$r=$ Koefisien korelasi $\left(r_{\text {hitung }}\right)$

$n=$ Jumlah responden

- Nilai $t_{\text {hitung }}<t_{\text {tabel }}$ berarti Ho ditolak dan Hi diterima, artinya tidak terdapat pengaruh secara parsial.

- Nilai $t_{\text {hitung }}>t_{\text {tabel }}$ berarti Ho diterima dan Hi ditolak, artinya terdapat pengaruh secara parsial.

\section{HASIL DAN PEMBAHASAN \\ Analisis Jalur Pengaruh Fasilitas Kerja dan Kompetensi terhadap Kinerja melalui Kepuasan Kerja pada Kantor Kelurahan Sekecamatan Muara Bulian Kabupaten Batang Hari}

Dalam analisis ini, diperlukan nilai koefisien jalur baik jalur fasilitas kerja terhadap kepuasan kerja, maupun jalur kompetensi terhadap kepuasan kerja, jalur fasilitas kerja terhadap kinerja, jalur kompetensi terhadap kinerja, dan jalur kepuasan kerja terhadap kinerja. Pada pembahasan di atas telah diketahui koefisien masing-masing jalur. Berikut koefisien keseluruhan jalur dalam penelitian ini :

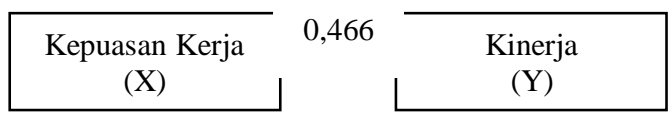

Gambar 3. Koefisien Jalur

Berdasarkan pada gambar di atas, dapat kita lakukan perhitungan mengenai pengarauh fasilitas kerja dan kompetensi 
terhadap kinerja melalui kepuasan kerja. Berikut adalah perhitungan pengaruhnya :

$$
\begin{aligned}
& \begin{array}{l}
\text { Pengaruh Kepuasan Kerja terhadap } \\
\text { kinerja }
\end{array} \\
& \begin{aligned}
\mathrm{X}_{1} \Omega \mathrm{Y} \rightarrow \mathrm{Z} & =(\mathrm{PYX})(\mathrm{PYX}) \\
& =0,466 \times 0,466 \\
& =0,2172 \\
& =21,72 \%
\end{aligned}
\end{aligned}
$$

\section{Uji t}

Hipotesis menyatakan kepuasan kerja berpengaruh secara parsial dan signifikan terhadap kinerja pegawai pada Kantor Kelurahan Sekecamatan Muara Bulian Kabupaten Batang Hari. Berikut hasil pengujiannya :

Tabel 1. Nilai $t$ Hitung dan $\mathbf{t}$ Tabel Kepuasan Kerja terhadap Kinerja

\begin{tabular}{cccc}
\hline Variabel & $\mathbf{t}$ hitung & $\mathbf{t}$ tabel & Sig. \\
\hline $\begin{array}{c}\text { Kepuasan } \\
\text { Kerja }\end{array}$ & 2,177 & 1,67722 & 0,000 \\
\hline \multicolumn{2}{l}{ Sumber : Data diolah }
\end{tabular}

Pada tabel di atas, dapat diketahui bahwa nilai t hitung untuk kepuasan kerja sebesar 2,177, nilai t tabel sebesar 1,67722, dan nilai Signifikan di bawah 0,05 $(0,000)$. Nilai $\mathrm{t}$ hitung $>$ nilai $\mathrm{t}$ tabel (2,177>1,67722), maka kepuasan kerja berpengaruh secara parsial dan signifikan terhadap kinerja pegawai pada Kantor Kelurahan se Kabupaten Batang Hari.

\section{SIMPULAN}

Berdasarkan pada pembahasan dapat ditarik kesimpulan bahwa pengaruh kepuasan kerja terhadap kinerja sebesar 21,72\%. Dan Kepuasan Kerja berpengaruh secara parsial dan signifikan terhadap Kinerja pegawai pada Kantor Kelurahan se Kabupaten Batang Hari.

\section{DAFTAR PUSTAKA}

Anak Agung Ngurah Bagus Dhermawan, dkk. 2012. Pengaruh Motivasi, Lingkungan Kerja, Kompetensi, Dan Kompensasi Terhadap Kepuasan Kerja Dan Kinerja Pegawai Di Lingkungan Kantor Dinas Pekerjaan Umum Provinsi Bali. Bali : OJS Universitas Udayana
Awaludin K., dkk. 2013. Pengaruh Pemberian Fasilitas, Tingkat Pendidikan Dan Disiplin Kerja Terhadap Peningkatan Kinerja Pegawai Pada Badan Busat Statistik Kabupaten Maros. Program Magister Manajemen Universitas Hasanuddin

Dahlias, Apri dan Ibrahim Mariaty. 2015. Pengaruh Fasilitas Kerja terhadap Kepuasan Kerja Karyawan pada PT. Bank Riau Kepri Cabang Teluk Kuantan Kabupaten Kuantan Singingi. JOM FISIP Vol. 3 No. 2Oktober 2016

Departemen Pend. Nasional. 2008. Kamus Besar Bahasa Indonesia. Jakarta: PT Gramedia Pustaka Utama.

Fred, Luthans. 1998. Organizational Behavior: Instuctor's Resources Manual and Test Bank. New York: International Book Company

Fuad Mas'ud. 2004. Survei Diagnosis Organisasional. Semarang : Badan Penerbit Universitas Diponegoro

Gibson, James L. et al. 2004. Organisasi : Perilaku Struktur Dan Proses. Alih bahasa : Ir. Hunuk Adiarni,MM. Jakarta : Bina Rupa Aksara

Ghozali, Imam. 2011. Aplikasi Analisis Multivariate dengan Program SPSS. Semarang: Badan Penerbit Universitas Diponegoro.

Gomes, Faustino Cardoso. 2003. Manajemen Sumber Daya Manusia. Yogyakarta : ANDI

Handoko, T. Hani. 2003. Manajemen. Yogyakarta: BPFE.

\section{Manajemen}

Personalia dan Sumber Daya Manusia. Yogyakarta: BPFE.

Hartanto, L. 2000. Manajemen Personalia. Jakarta: PT. Radjagrafindo

Hasibuan, Malayu. 2007. Organisasi dan Motivasi Dasar Peningkatan Produktivitas. Jakarta: PT. Bumi Aksara.

Sumber Daya Manusia. Jakarta: Bumi Aksara. 
Hutapea, Parulian dan Nurianna Thoha. 2008. Kompetensi Plus. PT. Gramedia Pustaka Utama: Jakarta

Kaswan. 2012. Manajemen Sumber Daya Manusia untuk Keunggulan Bersaing Organisasi. Yogyakarta: Graha Ilmu.

Kreitner, Robert dan Kinicki, Angelo. 2005. Perilaku Organisasi. Jakarta: Salemba Empat

Lund Daulatram. 2003. Organization Culture and Job Satisfaction. Journal of business and Industrial Marketing. Vol 18 No 32003 pp.219-236.

Mangkunegara Anwar.P (2000). Manajemen Kepegawaian Dan Sumber Daya Manusia, Bandung . 2009. Manajemen Sumber Daya Manusia Perusahaan. Bandung: PT. Remaja Rosda Karya.

Mariam, Rani. 2009. Pengaruh Gaya Kepemimpinan Dan Budaya Organisasi Terhadap Kinerja Karyawan Melalui Kepuasan Kerja Karyawan Sebagai Variabel Intervening Studi Pada Kantor Pusat PT.Asuransi Jasa Indonesia (Persero). Semarang : UNDIP

Moenir. 2003. Pendekatan Manusiawi dan Organisasi terhadap Pembinaan Kepegawaian. Jakarta: PT Gunung Agung.

Riduwan. 2012. Skala Pengukuran Variabel-Variabel Penelitian. Bandung: Alfabeta

Robbins SP dan Judge. 2002. Perilaku Organisasi. Jakarta : Salemba Empat

Rosidah dan Ambar T. Sulistiyani. 2003. Manajemen Sumber Daya Manusia. Cetakan. Pertama. Penerbit Graha Ilmu.

Sudarmanto. 2009. Kinerja dan Pengembangan Kompetensi SDM. Yogyakarta: Pustaka Pelajar.

Sugiyono. 2010. Metode Penelitian Kuantitatif Kualitatif dan $R \& D$. Bandung: Alfabeta.
Suharsimi, Arikunto. 2010. Prosedur Penelitian Suatu Pendekatan Praktik. Jakarta: Rineka Cipta Supriyanto, Yudi. 2015. Kompetensi Dan Komitmen Organisasional Terhadap Kepuasan Kerja Dan Kinerja Karyawan Koperasi. Prosiding Seminar Nasional 9 Mei 2015

Umar, Husein. 2002. Metode Riset Komunikasi Organisasi. Jakarta: PT Gramedia Pustaka Utama. 